\title{
Sociology back to the Publics
}

\begin{abstract}
$\underline{\text { Abstract }}$
This paper is a reading of the 'new sociology' that is mainly identified with the works of C. Wright Mills and Alvin Boulder. Its main argument is that the new sociology has given back a public face to sociology during the past forty years. This is arguably different from the 'old sociology' that has not been able to free itself from private social values. It is argued that Mills' power elite and Boulder's coming crisis theses have provided the foundation for many new sociologists' common enterprise to develop a critical and public sociology, which is informative for shaping what Mills called a 'democratic society of publics'. The new sociologists share the same critique of modern societies, namely, that though most modern societies have formal democracies, a substantial democratic social structure of publics is often lacking, due to the erosion of the public sphere by private values.
\end{abstract}

Keywords: coming crisis, power elite, public sociology, reflexivity, sociological imagination, welfare state

\section{Introduction}

This essay is a reading of the 'new sociology' that has flourished during the past forty years. This new sociology that finds its origins in the works of C. Wright Mills (Horowitz, 1964; Levine, 2005), sets itself the mission of retrieving and reviving the public social face of sociology, to shape a 'democratic society of publics'. It, indeed, criticizes the 'old sociology', the sociological establishment or ‘academic sociology' (Gouldner, 1971), for having effaced this public face to make place for a private face. It blames the old sociology, which it identifies with sociologists like Talcott Parsons, Samuel Stouffer, William Ogburn, Elton Mayo, Neil Smelser and James Coleman, for having failed in assuming its responsibilities for the creation and maintenance of a democratic society - where 'truth and justice will somehow come out of society as a great apparatus of free discussion' (Mills, 1956: 299).

This paper argues that the conflict between the new and the old sociology is ultimately a struggle between the 'sociology of the citoyen' and the 'sociology of the bourgeois'. From the new sociological viewpoint, the old sociology is a 'bourgeois science' (Gouldner, 1985: 193), 'bureaucratic social science' (Mills, 1959: 101), or 'administrative sociology' (Gouldner, 1971: 475). The old sociology is committed to the bourgeois social values, such as autonomy, meritocracy, instrumental rationality, utility, technocracy, comfort and money. The new sociology sets itself the task of being a 'public sociology' that is committed to the classical moral values or public values of citizenship, 
namely, liberty, human dignity, Socratic reason, democracy and moral virtue (Mills, 1959; Simon, 1995: 31).

The new sociology blames the old sociology for not having been careful and responsible with its creative power to shape society, and hence for not having sought public norms to guide its activities. According to the new sociology, the old sociology has contributed towards the shaping of a 'bourgeois public' (Mills, 1956: 303; Habermas, 2001: 27; Gouldner, 1976: 139), in and through its general theory of society and unified methodology, identified as the scientific method (Mills, 1959: 57) or 'comparative method' (Nisbet, 1986: 55-6) and defined as 'abstracted empiricism' (Mills, 1959) or 'mindless empiricism' (Gouldner, 1976: 11). In the old sociology, the (bourgeois) public consists of workers, consumers and clients, rather than citizens who are able to transcend their own interests and needs (c.f., Gouldner, 1973: 67). Mills (1956: 303-4; Habermas, 2001: 249) stresses that a real, democratic public, by contrast, means that

‘(1) Virtually as many people express opinions as receive them. (2) Public communications are so organized that there is a chance immediately and effectively to answer back any opinion expressed in public. Opinion formed by such discussion (3) readily finds an outlet in effective action, even against - if necessary - the prevailing system of authority. And (4) authoritative institutions do not penetrate the public, which is thus more or less autonomous in its operations.'

This essay begins with the initiator of the new sociology, C.Wright Mills and his power elite thesis. It is then shown that, even though Mills' theory of the degenerate bourgeois public was not uncritically and unanimously accepted by new sociologists, it did set the foundations for the new sociology. It played a major role in defining the areas to be studied, the sociological questions to be asked and the sociological or scientific norms to be obeyed. These norms, it will be shown, will prove crucial for new sociologists to liberate sociology from power systems, to make it what it is meant to be: a moral liberating enterprise. In Alvin Gouldner's coming crisis thesis, it can be seen why the new sociology accuses the old sociology of being a bourgeois enterprise. The following part, then, shows how the new sociology turns to reflexivity, to regain its liberating potential. Finally, the current state of affairs within the new sociology is examined, specifically concentrating on contemporary calls for a new sociological imagination and Michael Burawoy’s plea for revitalizing public sociology.

\section{The fall of democracy: the power elite thesis}

C. Wright Mills believes that the great problem of the modern age is intellectual and moral degeneration, that is, 'the decline of politics as genuine and public debate of alternative decisions' (Mills, 1956: 274). According to Mills (1956: 321), the more modern society has progressed, the more the modern mind has lost its political capacity to influence, by reflection and debate, issues of 
structural relevance, and the more antidemocratic the social structure has accordingly become. Mills (1959: 188) observes that, though most modern societies do have a formal democracy, their social structure, of the family, neighbourhood, party, state, corporation and education, is no longer democratic, but has increasingly grown bourgeois. Mills and the new sociologists stress that publics, in the form of townships, town meetings and forums, have gradually declined, when private concerns, in particular, corporate interests, have come to dominate the polity (Bellah e.a., 1985; Sennett, 1986; Lasch, 1995; Horowitz, 1999).

The new sociology is characterised by the thesis that systems of government embody the mind of the rulers. In its view, the rulers - those who are in command of the top positions in government, business and army - are not separate autonomous powers that keep each other in check, but constitute one power elite in its specific way of thinking. Mills' power elite thesis concerns the gradual deterioration of the mind of the power elite as a social fact: 'it is this mindlessness of the powerful, which is the true higher immorality of our time' (Mills, 1956: 342). For Mills, a good power elite is one that is committed to truth and the public values - democracy, self-government and human dignity. A mediocre power elite has its mind governed by fictions, bad taste and a non-philosophical language. Hence, Mills' observation that 'George Washington in 1783 relaxed with Voltaire's "letters” and Locke's “On Human Understanding”; Eisenhower read cowboy tales and detective stories' (Mills, 1956: 350) illustrates the new sociological argument that the mind of the power elite has forsaken philosophy for the sake of pleasure and mediocrity.

Since the power elite of statesmen has gradually declined to give place to the increasing power of corporate executives at the top positions of society, the governed have gradually lost their public understanding of the virtues. A corporate ruling group as such, does not need to be opposed to democratic rule or formal democracy. It is only when the corporate mind infiltrated and shaped the system of government that corporate power became the mortal enemy of democracy. The new, corporate power elite introduced corporate systems of government, characterized by corporate strategies, marketing, publicity, entertainment, bribery, intimidation, secret surveillance and image building, thereby transforming publics into media markets (Mills, 1956: 304). The corporate power elite does not perceive the governed as citizens or political persons, but as a bourgeois public of private individuals, who are workers, consumers, spectators, clients or property owners.

The bourgeois public, according to Mills, is antidemocratic because it creates indifference towards public issues by privatising social problems. The bourgeois is incapable of perceiving private troubles as public issues. To reanimate a democracy of publics, therefore, the deterioration of the power elite's mind, that is, 'the mindlessness and mediocrity of men of affairs' (Mills, 1956: 354) or 'the second rate mind' (Mills, 1956: 360-1), must be checked and reversed. The mind must regain that public relevance or democratic quality that enables the governed to see the public dimension in their own private troubles and to embrace social problems as their own. This democratic quality of the mind is what Mills calls 'the sociological imagination'. The Sociological Imagination (1959) is his public 
sociological attempt to shape a democratic social structure, in which the governed would be virtuous enough to govern their own affairs and powerful enough to deal with their own social problems in publics (Horowitz, 1963: 28).

\section{The new sociology after Mills}

New sociologists differ in their concepts and modes of analysis but do share the common thesis that the mind of the ruler, through the mediating systems of government, shapes the mind of the ruled. As Alvin Gouldner (1973: 167-8) puts it, 'it is the quality of mind, not politics, that confronts us with the deepest abyss'. According to Gouldner, who explicitly states that his 'standpoint remains very much that of the C. Wright Mills whose own radicalism and reflexivity was never expressed as a commitment to Marxism' (Gouldner, 1976: xiv), the mind of the corporate power elite is ruled by ideology. Ideology, for him, is an intellectual disease that penetrates into systems of government, which distort, or manipulate the opinions of the governed by creating a false consciousness of social reality. When ideology penetrates the public sphere, the governed are provided with ready-made opinions, which makes critical thinking, political engagement and debate redundant.

In contrast with Gouldner, new sociologists like Jürgen Habermas and Michel Foucault characterize the mind of the power elite in terms of its technology and instrumental rationality respectively. Foucault (1991) introduces the concept of 'governmentality' to show how the mentality of the governed, the form of understanding that the governed create about themselves and others, is affected by technological systems of government. Such systems include the complex of policy programmes, calculations, techniques, apparatuses, documents and procedures, which the power elite commands to persuade, induce, manage, incite, motivate and encourage the governed. Habermas, on the other hand, points out that ruling is increasingly exercised through the manipulation of public opinion, which depresses the critical faculties of the governed, making them a gullible public. Habermas argues that corporate decision making systems are organized to win the support of the governed through 'a staged display' and mood engineering. Arguments are transmuted into symbols to which the governed cannot respond by arguing but only by identifying themselves with them (Habermas, 2001: 206).

Though new sociologists may emphasize different elements that dominate the mind, they all agree that these 'intellectual diseases' are part of the sociological establishment. Instead of being a science that can critically observe and judge any system of government, the old sociology is itself shaped by these coercive systems of government. The new sociology attempts to resist the temptation of letting itself be included within the power elite. For instance, when the new sociology became highly popular under the student movement of the sixties, it did not associate itself with the latter's ideology of the new left (Gouldner, 1971: 405-10). Irving Louis Horowitz (1964: 18) had anticipated the new left ideological reaction to Mills' work and stated that 'Mills was a conservative sociologist in 
the true meaning of the words, for he was interested in preserving the heritage of the area. He referred to his own position as being in the "classic tradition"'.

In order to remain and survive outside the ruling systems of government, and organize themselves as a publicly responsible enterprise, new sociologists ground their works on the 'classic tradition' (Mills, 1959), 'sociological tradition' (Nisbet) or 'main currents' (Aron). Their association with the great sociologists is by no means a procedure for one standard judgment, but is a continuous process of reinterpretation and re-appropriation of sociology (Gouldner, 1973: 16; Burawoy, 2005a: 266). In the new sociological view, sociology is a social activity that builds on many generations of sociologists, who, in their commitment to truth, have, throughout time, evaluated their empirical findings through critical discourse. They argue that sociology, like all science, does not depend on the government, but on the existence of an independent scholarly community of living and dead sociologists, in which presuppositions are criticized in an ongoing Socratic dialogue.

Though several classical sociologists, such as Tocqueville, Durkheim and Veblen, are key figures for the new sociologists, many of them identify Max Weber as the exemplary personification of their commitment to truth above any other motive. Weber's Science as a Vocation, which C. Wright Mills and Hans Gerth had published in 1946, in particular, plays a special role in the development of the new sociology of science as 'intellectual craftsmanship' (Mills, 1959). Weber gives the most explicit guidelines as to how new sociologists can actually fulfil their public calling as scientists. He describes the calling of sociologists as 'an inner devotion to the task, and that alone, should lift the scientist to the height and dignity of the subject he pretends to serve' and teaches that the sociologist 'stands in the service of "moral" forces; he fulfils the duty of bringing about self-clarification and a sense of responsibility' (Weber, 1958: 137; 152). For Mills (1959: 173), herein lies 'the moral and intellectual promise of social science', that is to say, 'that freedom and reason will remain cherished values, that they will be used seriously and consistently and imaginatively in the formulation of problems.'

\section{Welfare state sociology: the coming crisis}

New sociologists critically point out that the old sociology's grand theory of society reflects the mind of the corporate power elite. They also insist that the old sociological commitment to a unified empiricist methodology is shaped by the ideology, technology and rationality of corporate systems of government. In the 1930's, corporate ideological systems, in particular, laissez-faire liberalism, in combination with corporate technological systems, like market research and public opinion research, brought statistics into the heart of government. Since the old sociologists were dependent upon the corporate power elite, for their position and existence, they have eventually absorbed the power elite's corporate social values. New sociologists blame the old corporate sociology for having no (sociological) mind of its own, having absorbed that of the corporate power elite. The old sociology 
fails to perceive how its own mind and its depiction of society through its use of datasets, variables and causal relationships or correlatives are shaped by systems of government, and how it irresponsibly contributes towards the shaping of mentalities, disregarding the moral question of good and evil.

Mills (1963: 37) states that, for the new sociology, 'the idea of a society that is at bottom composed of publics is not a matter of fact; it is the proclamation of an ideal'. Indeed, for new sociologists, it is the enormous divergence of the current, factual state of affairs from the classical ideal of the democracy of publics, which is the great problem of modernity. Mills observes that the gradual transformation of the mind of the power elite, from the statesman's mind of the 'citoyen' to the corporate mind of the 'bourgeois', has reached its climax in the Eisenhower administration. Gouldner, however, notes that the new left liberalism of the sixties, and the transformation of corporate systems into welfare state systems, reveal an even greater degeneration of the corporate power elite. According to Gouldner, under welfare state conditions, publics are superseded, managed and controlled by welfare organizations, on the basis of their knowledge systems and their relative power positions (Gouldner, 1976: 139-40).

During the Eisenhower administration, the ideology in support of the underdog, which Gouldner calls 'liberalism', was still peripheral; it was still the ideology of a minority fighting against the political, corporate and military status quo. After the social movements of the sixties, however, Gouldner (1971: 501; 1973: 146-7) observes that 'liberalism today is itself a powerful establishment... Liberalism today is not an "outsider's" politics; it is a central part of the governing political apparatus'. The liberalism of the new left redefines the governed as welfare needy. It assigns each social problem to a specific welfare agency that is technically designed for problem-solving. New sociologists identify the development of welfare systems as the emergence of unprecedented state power, as the expansion of the Leviathan (Gouldner, 1971: 76-7; Shils, 1997: 134-5; Horowitz, 1999) which embodies severe 'totalitarian tendencies' (Berger and Neuhaus, 1977: 3).

Gouldner (1973: 68) stresses that liberalism creates a false public consciousness through its claim that its welfare systems represent and defend all the diverse interests of the governed equally. Indeed, according to him, the liberal commitment to welfare is not a commitment to the welfare of the governed, but a commitment to the corporate value of utility. The welfare state's tentacles grabbed the old sociology whose private face, as a result, also underwent a surgery. The coming crisis thesis holds that, during the sixties, the old sociology changed from a corporate sociology into a 'welfarist sociology’ or ‘sociological Keynesianism' (Gouldner, 1971: 351). In The Coming Crisis, Gouldner observes that the general theory of the old corporate sociology has changed dramatically during the sixties. Previously, until the sixties, old sociologists had always advocated a limited role for the state in its grand theory of society. During the sixties, it appeared that their general theory could no longer account for the social changes, the social protests of the civil rights movement, anti-war movement and student movement, which were taking place. 
From the old sociology's perspective, social disorder is a symptom of either an error in the system or a redundant system. As the protest movements were no longer marginal or peripheral but appeared powerful enough to upset the establishment through violence and revolt, the old sociology changed its general theory to eliminate and prevent such disorder. It, therefore, included welfare state intervention in its general theory. Gouldner (1971: 342) singles out Talcott Parsons as the personification of the crisis within the old sociology. Before the sixties, Parsons' grand theory supported voluntarism and laissez-faire policies, but when the systems of government changed into welfare systems the older Parsons changed his mind and started advocating welfare systems' intervention in determining social outcomes, as 'a gyroscopic engine of social order' (Gouldner, 1971: 162).

\section{Overcoming the crisis: the birth of reflexivity}

When Mills wrote his Sociological Imagination, he could still hope that sociology could be returned to the publics from whence it emanated, because the power elite did not yet intervene in all corners of society. Private troubles and social problems could still be 'accepted as entities in the world, to be solved at the level at which people encounter them' (Horowitz, 1964: 21). With the advent of the welfare state in the sixties, however, social problem-solving no longer takes place at the level of publics, but becomes a task for white-collar professionals, who, trained in welfarist sociology, work in relatively autonomous welfare agencies, like schools, hospitals, nursing homes, elderly homes and social welfare institutions. These professionals believe in the superiority of their own knowledge, which is the knowledge of the old welfarist sociology, its general theory and empiricist methodology, while they presume to act for the well-being of the governed. This presumed superiority and 'benevolent humanism' legitimise the intrusion of professionals, and the spread of their liberal, bureaucratic ethos into all spheres of moral and intellectual life (Gouldner, 1971: 508-9; 1985: 34).

The pressing question, for Gouldner, is how to get out of this crisis and return sociology to the publics so that it can respond to its calling and fulfil its liberating potential. For this, he argues, an additional quality of mind is needed, which is 'reflexivity'. Reflexivity is a critical capacity of being conscious of the presence of the sociologist's subjectivity in sociological works, of the social conditions that have enabled sociologists establishing themselves in society, and of the public implications of sociological theories for the governed (Gouldner, 1973: 77; 97). A reflexive sociology is a sociology of sociology, which studies how sociologists are involved in creating theoretical concepts that eventually shape the mentality of the governed. It is a sociology that sees the world, not as an entity that exists independently of the mind of sociologists, but as a social order that is created, destroyed and recreated by the implementation of sociological theories and application of research technology (Gouldner, 1973: 105). 
According to Gouldner (1971: 502), 'the historical mission of a reflexive sociology is to foster a critical awareness of the character of contemporary liberalism'. He (1971: 508-9) holds that 'reflexive sociology rejects the imperialistic ideology of men who seek to dominate a universe that they tacitly view as “theirs".' Reflexive sociology is the new sociological alternative to welfare state sociology that new sociologists believe to be repressive because it takes away the freedom of the governed to settle their own social problems, through self-government in publics. Welfare state sociology is oppressive in its imperialism: it is motivated by a passion for control. A reflexive sociology is needed to regain sociology's liberating, public force that the classical sociologists had provided. As Gouldner (1971: 495) puts it, 'a reflexive sociology embodies a critique of the conventional conception of segregated scholarly roles and has a vision of an alternative. It aims at transforming the sociologist's relation to his work'.

Pierre Bourdieu believes that the liberating force of reflexive sociology lies in its critical sociological attempt to check what he calls 'symbolic violence' that professionals, including sociologists, inflict on the governed. As a new sociologist, Bourdieu (1992: 194) states that 'reflexivity makes possible a more responsible politics'. In contrast with Mills and Gouldner, Bourdieu (1992: 69-70) holds that it is not so much the deterioration of the quality of mind of the power elite and the mindlessness of old sociologists, which breaks down the democracy of publics. Instead, it is the 'intellectualist bias' of professionals, including the bias of sociologists, which inflicts a type of symbolic domination, preventing the governed from becoming genuine political agents. By unveiling the class positions and privileges of professionals within the welfare state, Bourdieu develops his reflexive sociology in a deliberate attempt to show how professionals prefer their own judgements, standards and methods to the practical lay knowledge of the governed.

\section{The new sociological imagination}

Contemporary new sociologists unanimously agree that the great issues of our time differ from those of the sixties and seventies. Today it is no longer welfarism but global capitalism that generates a coming crisis. The old sociology is now included in the think tanks, research institutes and consultancy firms of global capitalist systems of government, while its private face is disguised behind new masks like management science and crime science. What is then the relevance of the new sociology of Mills and Gouldner in the contemporary context shaped by globalisation? There are two main, different sociological reactions to the new challenges. The one sees global capitalism as threatening the new sociology and citizenship. The other sees new possibilities for returning sociology to the publics under global conditions in world citizenship and presses for a 'reinvention' of the new sociology, in the form of a 'new sociological imagination' (Beck, 2000: 134; Fuller, 2006).

Richard Sennett (1998) stands in the tradition of the power elite thesis that now, however, has to take into account the new conditions of flexible work, loose networks and geographical mobility 
that define the 'new capitalism'. He perceives globalisation as a destructive force, as the globalisation of the power elite and hence, foresees an even greater repression of the publics. According to Sennett, globalisation destroys the necessary condition for citizenship: the fixed boundary of the democratic nation-state that endows its citizens with rights and duties. In other words, the community of locals who know and trust each other is essential for citizenship. The new capitalist power elite is global and in its scope and organizes itself in global systems of government like the World Economic Forum. It is diverse in its nationalities, but united in a common cosmopolitan bourgeois mind. It works with omnipotent power to constitute a global bourgeois public of consumers, under the domination of the large trans-national organizations that it commands. As the new power elite's neo-liberal ideology is hostile to the very idea of society, Sennett is pessimistic about the democratic opportunities for returning sociology to the publics. Public man has fallen since long, while the new sociology is too marginalized to resurrect him.

New sociologists like Sennett point out that the corporate social values of the global power elite have infused into all little corners of the world. As a result, the nature and quality of citizenship, work, family, neighbourhood, education, statehood and even warfare have further degenerated, while the governed have become more powerless. In the global, flexible and mobile world, they have become 'strangers' to one another (Ossewaarde, 2007). Global capitalism is the corrosion of publics (Turner, 2006: 146). Yet, there are other new sociologists, such as Ulrich Beck and Anthony Giddens, who believe that globalization offers new opportunities for the new sociology and the revitalization of publics. They actually welcome globalisation as a force that weakens the national power elites and hence making their various systems of government less effective. This leads to a revitalization of the publics. Citizenship, according to these sociologists, is being reinvented, assuming new post-national, trans-national and cosmopolitan forms.

These more optimistic new sociologists agree that, under global conditions, the governed are still unable to make private and local troubles like AIDS, global heating and genetic manipulations into global issues. Like Mills, Gouldner and Sennett, they point out that corporate scandals, military adventures abroad and a failure to settle environmental issues certainly betray the 'organized irresponsibility', 'white-collar crime' and 'indifference to the future' (c.f., Adam, 2004) of the power elite. Also, they develop a reflexive critique of the old sociology, particularly of its contemporary social pathological forms that are used to legitimate bio-political systems of government (c.f., Fuller, 2006: 47). Yet, they observe that a 'cosmopolitan imagination' (Beck and Sznaider, 2006: 3), located outside the established government systems, inside global publics, is under construction to equip the governed against possible calamities. Reflexivity is no longer an exclusive feature of the new sociology, but has come to define the identity of the governed who are now more involved, less ignorant, and less manipulable with respect to world affairs than their forbears were with respect to national affairs. 
'The unpolitical bourgeois of late capitalism as regulated by the welfare state is becoming a political bourgeois,' Beck (2000: 101) says. And though the political bourgeois of global capitalism is not yet fully democratic, (s)he is forced to criticize, to respond to the global challenges that escape the power elite's governmental control and act reflexively in publics to put the themes of an endangered world on the social agenda. Therein lies 'the possibility of democracy in a global age' (Beck, 2000: 14). Hence, the new sociological imagination, a cosmopolitan understanding of how global issues affect the sociologist and the governed personally, is a continuation of the new sociological project, grounded in the new ideal of a global democratic society of publics and world citizens. It is a new sociological quality of mind that is essential to see what publics and global citizens the global society is producing and what sorts of social problems are experienced by the governed worldwide.

\section{For public sociology, for 'democratic socialism'}

Michael Burawoy, like Sennett, believes that globalization poses a serious threat to sociology in general and to the new sociology in particular, holding that 'globalization is wreaking havoc with sociology's basic unit of analyses - the nation-state - while compelling deparochialization of our discipline' (Burawoy, 2005a: 262). Under conditions of global capitalism, it is no longer necessary for the new sociology to combat the old sociology's private face. Instead, Burawoy seeks to unite the old and the new sociology in a common cause, stressing that they have now become interdependent in their struggle for survival. Burawoy observes that the old sociological establishment no longer embodies the power elite's mind. Therefore, new, reflexive sociologists should no longer consider the old sociology as their enemy, but rather as the necessary condition for their own existence. Indeed, by guaranteeing the position of sociology in the university, the old sociology provides its new counterpart too with both legitimacy and expertise. New sociologists can thereby reach their extramural academic publics from the university site.

Burawoy (2005a: 276) redefines sociology and its complementary components, thereby changing the direction of the new sociology. The 'old sociology' consists of 'professional sociology' and 'policy sociology'. The first one is characterized by its general theory, empiricist methodology and academic self-referentiality; the other is in service of policy interventions, to improve the effectiveness of existing systems of government. The 'new sociology' consists of 'critical sociology' and 'public sociology'. Critical sociology develops a moral vision for sociology and criticizes the normative foundations of the old sociology in academic debates. Public sociology makes science for the publics, with the deliberate aim of improving the democratic quality of public opinion. The four sociologies are interdependent in their very existence: critical and public sociology is 'the complement and not the negation' of the old sociology (Burawoy, 2005a: 261).

By stressing the complementarity between the old and new sociologies, Burawoy undervalues the fundamental difference between the two. He disregards the fact that the new sociology's moral 
vision is inspired and guided by classical sociology. He, hence, also blurs the distinction between the bourgeois face of the old sociology and the public face of the new sociology. Burawoy (2005b: 313; 317-8) stresses that today's new sociologists should no longer try to convert the old sociology, but should instead join forces to confront the global threats and try to change the world, from the university site. In his view, today's new sociology ought not be inspired by a classical vision of democratic citizenship, liberty, human dignity and Socratic reason, but should be a progressive ideological, perhaps even revolutionary force in the era of global capitalism: contemporary new sociologists are 'accountable to some such vision of democratic socialism' (2005b: 325). Burawoy is explicit in his political alliance with the new left ideology, claiming that new sociologists are 'merely continuing the revolution in the university - bastion of power in the knowledge society' (2005b: 315).

Burawoy (2005b: 319) argues that public sociology in particular is meant to ally with the protest movements of civil society, 'to bolster the organs of civil society.' In his view (2005b: 321; 324), these movements act against a socially irresponsible power elite or 'state-business apparatus' that, in the global age, has become less concerned with their welfare mission and more with the corporate interest, so that social burdens are increasingly being downloaded onto the governed. For Burawoy, civil society is not a 'bourgeois society' or 'bürgerliche Gesellschaft' that expresses the private faces of factions, associations and social movements, but is the domain of publics struggling against capitalist domination (c.f., Ossewaarde, 2006). That is to say, in contrast with Mills and Gouldner, and also different from Sennett and Beck, Burawoy does not identify the civil society movements as being part of the global power elite. In his view (2005: 318), social movements, such as the anti-globalisation movement or anti-war protest movement, are publics that transform private problems into public issues. They are guided by a revolutionary vision of democratic socialism, of socially responsible civil society protest in 'the world [that] has become more reactionary.'

Burawoy is a new sociologist, in the sense that he seeks to return sociology to the publics. Publics, for him, however are the protest movements. He is a new sociologist because he adheres to the power elite thesis, and embraces reflexivity. He sees, in his optimist moods, public sociology as the queen of the science of the global age. Yet, he also strongly deviates from the new sociology as developed by Mills and Gouldner. For, these new sociologists were not democratic socialists, but were, in Horowitz's words, 'conservative', in the sense of being committed to classical values and sociological tradition. They see sociology and ideology as antithetical. As Burawoy's democratic socialism is a continuation of the liberalism of the new left, it fails to maintain the distance necessary for critical judgement and hence does not fit into the tradition of the new sociology. The new sociologists' critique of the welfare systems of government and liberalism is guided by a moral vision of the democratic society of publics. Burawoy's democratic socialism, on the other hand, embraces the welfare state as its own ideal. This uncritical stance on a system of government that was once regarded as destructive for publics deviates from the tradition of a critical, vigilant new sociology. 


\section{Literature}

Adam, B. (2004) Time. Cambridge: Polity Press.

Beck, U. (2000) World Risk Society. Cambridge: Polity Press.

Beck, U. and N. Sznaider (2006) 'Unpacking Cosmopolitanism for the Social Sciences: A Research Agenda', The British Journal of Sociology 57 (1): 1-23.

Bellah, R.N., R. Madsen, W.M. Sullivan, A. Swidler and S.M. Tipton (1985) Habits of the Heart: Individualism and Commitment in American Life. Berkeley: University of California Press.

Bourdieu, P. and L.J.D. Wacquant (1992) An Invitation to Reflexive Sociology. Cambridge: Polity Press.

Burawoy, M. (2005a) '2004 American Sociological Association Presidential Address: For Public Sociology', The British Journal of Sociology 56 (2), 2005: 259-294.

Burawoy, M. (2005b) ‘The Critical Turn to Public Sociology’, Critical Sociology 31 (3): 313-326.

Calhoun, C. (2005) 'The Promise of Public Sociology', The British Journal of Sociology 56 (3): 355363.

Foucault, M. (1991) 'Governmentality’, in C. Burchell e.a. (ed.), The Foucault Effect: Studies in Governmentality. London: Harvester Wheatsheaf, pp. 87-104.

Fuller, S. (2006) The New Sociological Imagination. London: Sage.

Gouldner, A.W. (1971) The Coming Crisis of Western Sociology. London: Heinemann.

Gouldner, A.W. (1973) For Sociology: Renewal and Critique in Sociology Today. London: Allen Lane.

Gouldner, A.W. (1976) The Dialectic of Ideology and Technology: The Origins, Grammar and Future of Ideology. London: Macmillan.

Gouldner, A.W. (1985) Against Fragmentation: The Origins of Marxism and the Sociology of Intellectuals. New York: Oxford University Press.

Habermas, J. (2001) The Structural Transformation of the Public Sphere: An Inquiry into a Category of Bourgeois Society. Cambrige MA: MIT Press.

Horowitz, I.L. (ed.) (1964) The New Sociology: Essays in Social Science and Social Theory in Honor of C. Wright Mills. Oxford: Oxford University Press.

Horowitz, I.L. (1999) Behemoth: Main Currents in the History and Theory of Political Sociology. London: Transaction Publishers.

Lasch, C. (1995) The Revolt of the Elites: And The Betrayal of Democracy. New York: WW Norton. Levine, R.F. (ed.) (2005) Enriching the Sociological Imagination: How Radical Sociology Changed the Discipline. Bouldner: Paradigm Press.

Mills, C.W. (1956) The Power Elite. New York: Oxford University Press.

Mills, C.W. (1959 The Sociological Imagination. New York: Oxford University Press. 
Mills, C.W. (1960) 'Letter to the New Left', New Left Review 5.

Nisbet, R. (1986) The Making of Modern Society. Brighton: Wheatsheaf Books.

Ossewaarde, M.R.R. (2006) 'Citizenship in Civil Society?’, Journal of Civil Society 2 (3): 199-215.

Ossewaarde, M. (2007) 'Cosmopolitanism and the Society of Strangers', Current Sociology 55 (3): ??.

Sennett, R. (1986) The Fall of Public Man (London: Faber and Faber, 1986).

Sennett, R. (1998) The Corrosion of Character: The Personal Consequences of Work in the New Capitalism. New York: Norton.

Shils, E. (1997) The Virtue of Civility: Selected Essays on Liberalism, Tradition, and Civil Society. Indianapolis: Liberty Fund.

Simon, D.R. (1995) Social Problems and the Sociological Imagination: A Paradigm for Analysis. New York: McGraw Hill.

Turner, B.S. (2006) 'Classical Sociology and Cosmopolitanism: A Critical Defence of the Social', The British Journal of Sociology 57 (1): 133-151.

Weber, M. (1958) From Max Weber: Essays in Sociology. Ed. H.H. Gerth and C. Wright Mills. New York: Oxford University Press. 